\title{
モデルダンパー内における電気粘性流体の挙動特性*
}

$\begin{array}{ccccc}\text { 山口 博 } & \text { 司*1, 島 田 邦 雄*2 } \\ \text { 張 信 栄*1, 井 上 大 輔*3 }\end{array}$

\section{Flow Characteristics of ER Fluid in Model Damper}

\author{
Hiroshi YAMAGUCHI ${ }^{* 4}$, Kunio SHIMADA, \\ Xinrong ZHANG and Daisuke INOUE \\ ${ }^{* 4}$ Department of Mechanical Engineering, Doshisha University, \\ 1-3 Tatara-Miyakodani, Kyo-Tanabe-shi, Kyoto, 610-0321 Japan
}

\begin{abstract}
A basic study of a gap flow in a closed piston-cylinder system of ER fluid was carried out. The purpose of this study is to elucidate flow behavior of ER fluid in the piston-cylinder system. The electric field is applied between inner wall of the cylinder and outer wall of the piston, and the pressure difference between upper and lower chamber of the piston is measured. Theoretical formula of pressure difference was obtained by the one-dimensional assumption of the flow in the gap of cylinder. Furthermore, simulation cord is developed in the present study based on the finite volume method (FVM) with moving boundary condition. In comparison with the theoretical approximation and experimental results, it was found that some difference occurrs in the case of the lower aspect ratio of the piston. However, when aspect ratio is large and piston speed is low, the theoretical approximation and experimental results show fair agreement. On the contrary the simulation results showed a good agreement with whole results in experiments.
\end{abstract}

Key Words: Damper, Pipe Flow, Finite Volume Method, Moving Boundary, Electro Rheological Fluid, Pressure Difference

\section{1. 緒}

非ニュートン流体の中で，外部電場に応答して流体 のレオロジー特性が変化する現象を電気レオロジ一効 果（以下 ER 効果）と言い(1)，特に ER 効果の大きい流 体を電気粘性流体（以下 ER 流体）と言う。ER 流体 は加える電土を変化させることで流体の粘性を制御で きる上，降伏応力が発生することから現在，様々な工 学的応用が考えられている(2) (3). 一方, ER 効果を利 用した機器を設計する上で, ER 効果の流体力学的視 点からの検討が必要不可欠(4)であるものの， ER 流体 を用いて流休力学的に取り扱う研究報告は少ない，ま た，これまでの研究報告では平行平板流路に関するも のが多く，エンジンマウントやダンパー等の振動制御 機器が持つ流動場の狭小流路形状における ER 流体の 挙動特性に関する報告例(5) は少ないのが現状である. そこで, 本研究では工学的応用例としてピストンと

* 原稿受付 2005 年 4 月 8 日

*1 正員, 同志社大学工学部 $-610-0321$ 京田辺市多々羅都谷 1-3).

*2 福島大学理工学群( 960 -1296 福島市金谷川 1).

$* 3$ 同志社大学大学院工学研究科.

E-mail : hyamaguc@mail.doshisha.ac.jp
シリンダにより構成されるモデルダンパー内における ER 流体の基礎的な挙動特性を調べることを目的とした. 実験ではまずレオメータを使用して ER 流体のレオロジ 一特性の調查を行った. 次にピストンに定速運動を加え て差圧を測定し，モデルダンパー内での ER 流体の圧力 特性を明らかにした。 また，シリンダ上下部での差圧の 近似式を求め, 様々なピストン速度, アスペクト比およ ひ印加電場における圧力測定値と比較を行った．さらに 二次元軸対称座標系において非圧縮，粘性流体を想定し 数值解析によりモデルダンパー内部の流体挙動を明らか にした.

\section{2.おもな記 号}

$\begin{array}{lll}E & \text { 直流電場 } \quad[\mathrm{kV} / \mathrm{mm}] \\ \Delta P & \text { 圧力差 (差圧) } \quad[\mathrm{Pa}] \\ U p & \text { ピストン速度 } \quad[\mathrm{m} / \mathrm{s}] \\ \dot{\gamma} & \text { せん断速度の大きさ } & {[1 / \mathrm{s}]} \\ \eta_{l:} & \text { 塑性粘度 } & {[\mathrm{Pa} \cdot \mathrm{s}]} \\ \tau & \text { せん断応力 } \quad[\mathrm{Pa}]\end{array}$

3. 実験 
$3 \cdot 1$ 供試流体 本研究において供試流体として 用いるのは十分な ER 効果が期待でき, 粒子が安定分 散する $3 \mathrm{w} \mathrm{w} \%$ の濃度のシリコーンオイルベースのスメ クタイト分散系 ER 流体である. 分散系 ER 流体は比 較的大きな ER 効果が得られる事が確認されており, メチルフェニルシリコーンオイル $(\mathrm{KF}-56$ 信越化 学製）を溶媒として，スメクタイトSPN（コープケミ カル製）を安定分散させたものを用いた．合成スメク タイト粒子は, 平均厚みが 2 50nm と非常に小さく 円盤状で比表面積が $710 \sim 760 \times 10^{3} \mathrm{~m}^{2} \mathrm{~kg}$, 密度が $2670 \mathrm{~kg} / \mathrm{m}^{3}$ であり，約 $1 \%$ 以下の水分を含む含水系の粒 子である. 図 1 の流動曲線に示されるように今回作成 した ER 流体は電場を印加するに従って明確な降伏応 力が生じることを確認した。
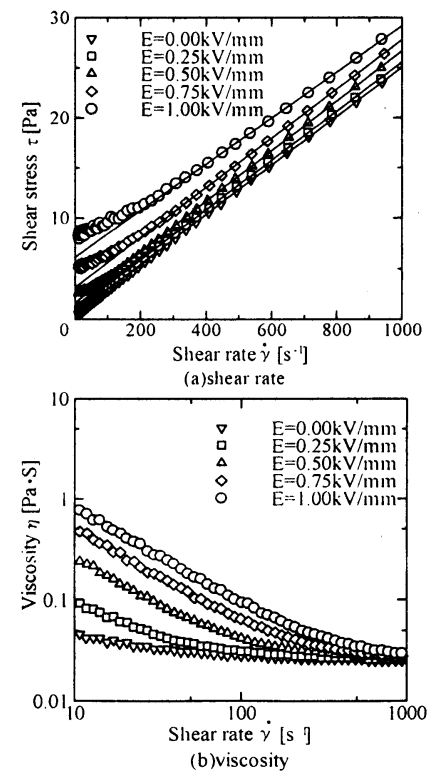

Fig.1 Flow curve of ER fluid $\left(22^{\circ} \mathrm{C}\right)$

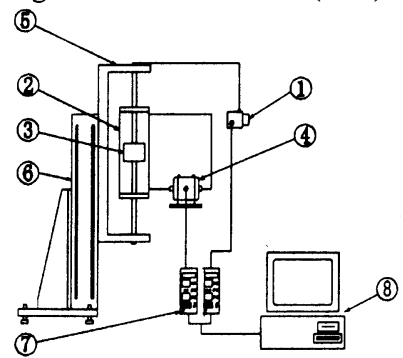

(1)Displacement transduœer

(5) Suspension arm (2) Cylinder (6) Robotmodule unit (3)Piston (7)Amplifier

(4)Different pressure transducer (8)Computer

Fig.2 Experimental apparatus
$3 \cdot 2$ 実験装置 モデルダンパーの概略を図 2 に示 す、ピストン運動は，ロボットモジュール(6)取り付 けたアーム(5)からピストンロッドへと動力を伝えるこ とによって行われる. シリンダ部の全長を $660 \mathrm{~mm}$ と し，シリンダ(2)内に供試流体を満たす。 シリンダ(2)の 内径は $44 \mathrm{~mm}$, ピストン(3)の直径は $40 \mathrm{~mm}$ とし, 間隙 は $2 \mathrm{~mm}$ とした. また，実験により得られるピストン 上下面の差圧については静圧孔をシリンダ壁面に設け， 差圧計(4)によって測定する. 測定した差圧はアンプ(7) (DPM-700B 型 共和電業製) を介してコンピュー 夕に取り込む.

3.3 実験条件 本研究では, モデルダンパー内で の ER 流体の基礎的な挙動特性について調べるため, ピ ストンに一定速度を加え, 以下に示すアスペクト比の条 件で実験を行った.

電場 $\quad E=0.0,0.25,0.5,0.75,1.0 \mathrm{kV} / \mathrm{mm}$

ピストン速度 $U p=20,60,100 \mathrm{~mm} / \mathrm{s}$

アスペクト比 $A s=0.25,0.5,1.0,2.0$

ただし，本実験装置ではピストン速度が 0 からUpに なるまで, $35.0 \mathrm{~m} / \mathrm{s}^{2}$ の加速度で上昇させるため, Up が $20 \sim 100 \mathrm{~mm} / \mathrm{s}$ となる立ち上け時間は $10^{-4} \sim 10^{-3} \mathrm{sec}$ の才 一ダーとなる. 従って, 本研究ではピストンはほぼステ ップ的に立ち上げているものとみなすことができる. ロ ボットモジュールの設定条件を以下に示す.

- 定速上昇運動

- 定速下降運動

ここで，本実験で用いた ER 流体のような低濃度の 流体では電気抵抗が小さくなり電流が流れ，ショートす る可能性が生じるために最大電場印加を $1.0 \mathrm{kV} / \mathrm{mm}$ とし

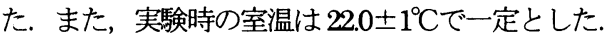

3.4 実験方法 実験に先立ち, レオメータにより $\mathrm{ER}$ 流体のレオロジ一特性を確認する.レオメータは, 外径 $40 \mathrm{~mm}$ の回転内筒と内径 $42 \mathrm{~mm}$ の静止外筒による 共軸二重円筒型レオメー夕を用いた，ER 流体は図 1 に 示すように電場印加時にはビンガム流体の性質を示し, 印加電場の増加に伴いせん断応力が増す傾向があるため, この性質をダンパーに利用できる.

本研究では, 本実験の動力部であるロボットモジュー ルにピストンに動力を伝えるためのアームを取り付け, ロボットモジュールの原点を調整する. また，シリンダ をアームと平行に取り付け, 実験液を満たし, 差圧計, 変位計を取り付ける. さらに, 電場印加の端子をシリン ダに接触させ，ピストンロッドの最下点にアースを取り 付ける. ここで, 安全のためにシリンダの外壁をゴムシ 一トで覆うものとした. 次に, 差圧計と変位計のゼロ点 
を合わせ，実験を開始する，実験においては再現性を 確認するために各実験条件下で 3 回計測を行った.

3.5 差圧近似理論式 シリンダ, ピストン間隙に おける流体の微小要素に働く圧力を $P$, 世九断応力を $\tau$ として, 管軸方向に $z$ 軸, 半径方向を $r$ 軸とするとき 次式が成立する。

$$
\frac{d P}{d z}+\frac{1}{r}\left\{\frac{d(\tau r)}{d r}\right\}=0
$$

ここで, せん断応力とせん断速度の関係はビンガム流 体の近似式を用いると以下の式で表せる.

$$
\tau=-\left(\eta_{\sharp} \frac{d u}{d r}+\tau_{l:}\right)
$$

但し， $\eta_{E}$ は塑性粘度(plastic visoosity)， $\tau_{\text {: }}$ は降伏応力 (yield stress), $u$ は $z$ 軸方向の流速とする. $\eta_{l:}$ は, $\dot{\gamma} の$ 関数である 3 次の外挿式から求める. $\eta_{E}$ は印加電場の 大きさにより形が異なり，無電場時は定数となる. (1)式 に $r d r$ を乗じてさらに積分操作を行うと，(2)式を用いて 以下の式が得られる.

$$
\frac{d P}{d z} \frac{r^{2}}{4}-\left(\eta_{i:} u+\tau_{i} r\right)=A \ln r+B
$$

但し，A，B は積分定数. 本研究では, 内円筒移動の 条件で実験を行うため, $r=r_{1}$ に $u=U p$ で動く内円筒, $r=r_{2}$ に固定外円筒があるとすると, 速度分布は

$$
u=u(r)
$$

$=\frac{1}{\eta_{E}}\left[\frac{1}{4} \frac{d P}{d z}\left(r^{2}-r_{2}^{2}\right)-\tau_{t:}\left(r-r_{2}\right)-\frac{\ln \left(/ / r_{2}\right)}{\left.\ln f_{1} / r_{2}\right)}\left\{\frac{1}{4 d z}\left(r_{1}^{2}-r_{2}^{2}\right)+\eta_{i} U p-\tau_{l}:\left(r_{1}-r_{2}\right)\right\}\right]$ となり, ここで, $r_{0}$ はピストンロッドの半径, $d P / d z$ は

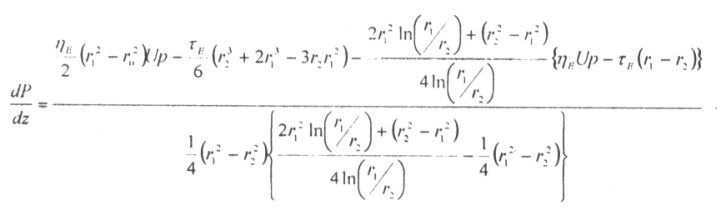

である.したがってピストンの外側壁面 $\left(r=r_{1}\right)$ 及び, シリンダの内側壁面 $\left(r=r_{2}\right)$ におけるせん断速度 $\dot{\gamma}_{1}$, $\dot{\gamma}_{2}$ はそれぞれ(4)式に $r_{1} ， r_{2}$ を代入することで得られる. また，ピストンの外側壁面におけるせん断力を $\tau_{1}$, シ リンダの内側壁面におけるせん断力を $\tau_{2}$ とおくと，管 軸方向に働く摩擦力と压力から求める力のつりあいより, ピストン長をl とすると, 上下面の差圧 $\Delta P$ は

$$
\Delta P=\frac{2 l\left(\tau_{1} r_{1}+\tau_{2} r_{2}\right)}{\left(r_{2}^{2}-r_{1}^{2}\right)}
$$

と表すことができる.ここで本研究では(5)式の $\tau_{1}, \tau_{2}$ に対し，それぞれの $\dot{\gamma}_{1} ， \dot{\gamma}_{2}$ に対応する值をレオロジ 一計測より得られるデ一タを用いた。

\section{4. 数值解析}

$4 \cdot 1$ 支配方程式 本研究では数值モデルとして二 次元軸対称座標系を設定した. 座標系には管軸方向を $z$, 半径方向を $r$ とする座標系を導入して計算を行った. 以 下に, 本研究の数值解析に用いた支配方程式を示す.

$$
\begin{aligned}
& \nabla \cdot \boldsymbol{u}=\mathbf{0} \\
& \rho \frac{D \boldsymbol{u}}{D t}=-\nabla p+\nabla \cdot \underset{\approx}{\tau}+\rho \mathbf{g}
\end{aligned}
$$

(6)式は連続の式，(7)式はコーシー方程式である。右辺第 2 項の $\tau$ は(2)式を応カテンソル型で表記したビンガム流 体の構成方程式である. また, 右辺第 3 項は, 重力によ る体積項である. 本研究で用いる ER 流体は電場に依存 して粘度が変化するため, 粘度 $\eta_{E}$ は(2)式のレオロジー 特性值から求めた值を用いるものとした.

$\mathbf{4 \cdot 2}$ 数值計算方法 本研究では, (6),(7)式を $(z, r)$ の直交格子で離散化した後, 有限体積法 (SIMPLE 法 (®) による反復計算を行い，時間進行で速度および圧力 について定常状態となるまで計算を行った。計算領域は, 図 3 に示すように実際のモデルダンパー形状に則した軸 対称領域を設定し， $660 \times 36$ に分割された直交スタッガ ード格子を用いた。本研究ではピストンーシリンダ間隙 付近で圧力, 流速の変化が最も大きくなるため, 軸中心 から半径方向に向かって格子間隔が密になる不等間隔メ ッシュを採用した，管軸方向については，等間隔格子と し, シリンダ内径を参照長さとして無次元化した。

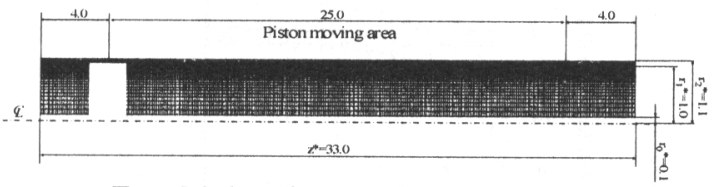

Fig.3 Mesh configuration for numerical analysis

$4 \cdot 3$ 移動境界条件 モデルダンパ一実験では固定 された（静止した）シリンダ内をピストンが与えられた 速度で運動するため, これを数值解析で実行する場合, ピストンの固体壁面位置を時々刻々変化させる必要があ る. まず，現時閒ステップにおいて，速度および圧力の 収束解が得られるまで反復計算を行った後, 次の時間ス テップへ進行する.この時ピストン固体壁が計算格子を 一つ隣へ移動し, その位置における新たな境界条件を付 与することで移動境界を実現する，本研究では流体に粘 性が存在するため norslip の条件を考え, ピストン上下 
面に隣接するセルの $z$ 方向速度成分はピストン速度とし て定義した. 以下に境界条件を示す.

$$
\begin{aligned}
& \text { シリンダ内壁面 } \\
& \text { ピストン上下面 } \quad: \quad u=U p \\
& u=0, v=0 \\
& \text { ピストンおよびロッド側面 ： } u=U p
\end{aligned}
$$

4.4 解析条件 モデルダンパー実験と同条件を設 定した

電場 $\quad E=0.0,025,0.5,0.75,1.0 \mathrm{kV} / \mathrm{mm}$

ピストン速度 $U p=20,60,100 \mathrm{~mm} / \mathrm{s}$

アスペクト比 $A s=025,05,1.0,2.0$

\section{5. 結果および考察}

\section{$5 \cdot 1$ ピストン速度の比較}

Table1. Response time of pressure difference $(A s=1.0)$

\begin{tabular}{ccccc}
\hline$E[\mathrm{kV} / \mathrm{mm}]$ & & 0.0 & 0.5 & 1.0 \\
\hline Response time & $U p=20 \mathrm{~mm} / \mathrm{s}$ & 6.0 & 7.1 & 7.5 \\
constant $\lambda_{4}[\mathrm{sec}]$ & $U p=60 \mathrm{~mm} / \mathrm{s}$ & 4.8 & 6.0 & 6.4 \\
\hline
\end{tabular}

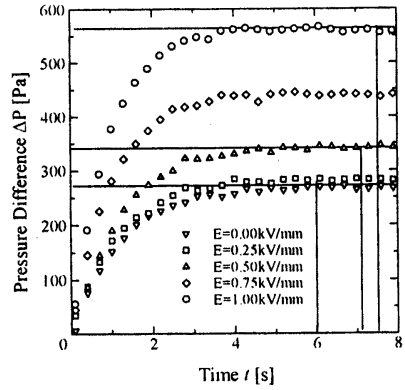

(a) $U p=20 \mathrm{~mm} / \mathrm{s}$

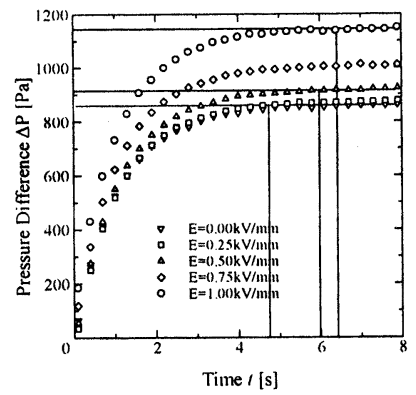

(b) $U p=60 \mathrm{~mm} / \mathrm{s}$

Fig.4 Transient characteristics of pressure difference $(A s=1.0)$

5.1.1 圧力応答時間 図 4(a),(b)は，それぞれ詨 応する数值解析結果として $A s=1.0$ における定速運動 での代表的楌測結果として Up $=20 \mathrm{~mm} / \mathrm{s}, U p=60 \mathrm{~mm} / \mathrm{s}$ の 圧力応答特性を示しており，図 5 はそれぞれに対応す る数值解析結果として $A s=1.0$ における各電場, ピス
トン速度条件下におけるシリンダ内部の流れ場の数值 解析結果を示す．また，表 1 に図 4 の結果として各ピ ストン速度における圧力が定常に達するまでの時間

(圧力応答時間 $\lambda_{1}$ ) を示す. (a) $E=0.0 \mathrm{kV} / \mathrm{mm}$ におけ る圧力応答時間は 6.0 秒となり, (b) $E=0.0 \mathrm{kV} / \mathrm{mm}$ にお
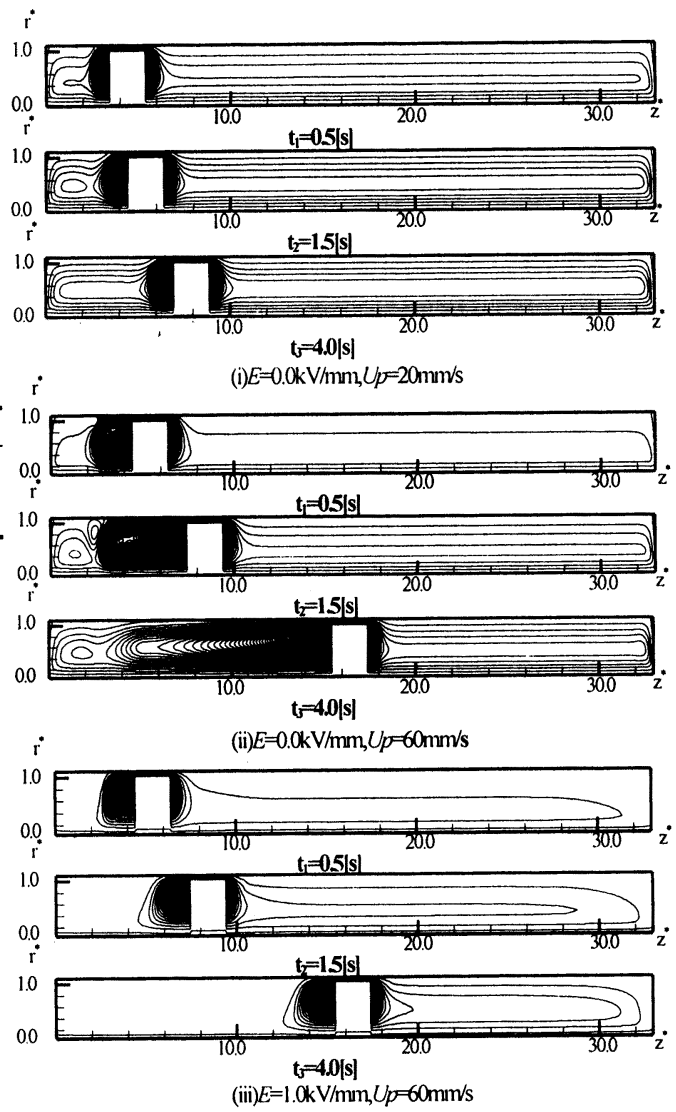

Fig.5 Flow fields $(A s=1.0)$

ける圧力応答時間は 4.8 秒となる. ここで，本研究で は圧力応答時間は, 定常值の約 $99 \%$ に達する時間とし た。この条件における流れ場を示した図 5(i)と(ii)を比 較すると，ピストン移動速度が速いほど急激な流れの 変化が生じている様子が確認できる．これはピストン 始動よりシリンダ内の流れ場, シリンダ内のピストン 上下空間における流れパターンの形成がそれぞれのピ ストン移動速度に依存するものである．また電場が上 昇するほど，ピストン速度のステップ立ち上げに対す る圧力応答時間は増加することが示された，例えば， 図 4(b)に示されるように, $E=1.0 \mathrm{kV} / \mathrm{mm}$ の印加電場で は圧力応答時間は $E=0.0 \mathrm{kv} / \mathrm{mm}$ （無電場）に対して約 
1.3 倍となることが分かる.これは，図 5(iii)に示すよ うに，同じピストン速度においても電場を印加するに 従って，ピストンーシリンダ間隙部における粘度が上 昇し, 流動抵抗が増加することで圧力伝達特性が変化 し, 流れの発達が遅延される事が考えられる.さらに, その傾向はピストン速度が小さいほど大きく現れるこ とが分かった. これはひずみ速度の上昇に伴って, 粘 度が減少する shear-thinning 性が寄与するためであると 考えられる. すなわち, 発達時間に対して印加電場の 上昇がモデルダンパーの圧力応答特性に大きく影響す ることが分かった，今回の数值解析でも差圧が一定に なるまでには，実験で観測された分に相当する時間が かかることが確認された．また，本研究では，クラス ター形成など ER 流体の粒子の緩和時間は msec.の才 一ダーであるとすると( , 流体の発達時間は 3 オーダ 一ほど高く, 緩和過程における現象への寄与は無視で きるものと考える.

$5 \cdot 1 \cdot 2$ 定常圧力值 各ピストン速度に対応寸る差 圧の定常值はピストン速度が速いほど大きくなる.これ は前述 (差圧近似式の導出) に示されるようにピストン とシリンダ壁のせん断応力がせん断速度に依存するため で，ピストン速度の上昇に伴い，せん断速度が上昇する ためである. また，電場の上昇に伴い，差圧の值も上昇 することが図 4 から分かる.これはシリンダとピストン 壁面におけるせん断応力が電場の増加とともにビンガム 流体的に上昇するためである.

\section{2 アスペクト比の比較}

\subsection{1 圧力応答時間 図 6 は $U p=20 \mathrm{~mm} / \mathrm{s}$ における} アスペクト比が 0.25 の圧力応答特性の計測結果を示し たものである. 図 4(a) と図 6 に見られるように, 同一電 場条件およびピストン移動速度条件において, アスペク 卜比による压力応答時間の変化が生じないことがわかる。 例えば，図 $4(2) E=0.0 \mathrm{kV} / \mathrm{mm}$ における圧力応答時間は 6.0 秒となり, 図 $6 E=0.0 \mathrm{kV} / \mathrm{mm}$ における圧力応答時間 も 6.0 秒である.この条件における流れ場を示した図 5(i)と図 7 を比較すると，ピストンの長さ分だけ流れ場 の位置がずれるものの, ほぼ同一の流れ場が形成されて いる様子が確認できる.これはシリンダ上下端付近の流 れ場とピストン周辺の流れ場が干渉し合わない限り，ア スペクト比の変化がピストンーシリンダ間隙以外の流れ 場形成に影響を及ぼさないためである。これは，いずれ のアスペクト比条件においても同様の傾向を示寸事が確 認された. すなわち, 発達時間に対してピストンのアス
ペクト比が圧力応答時間に影響を及ぼさないことが分か った.

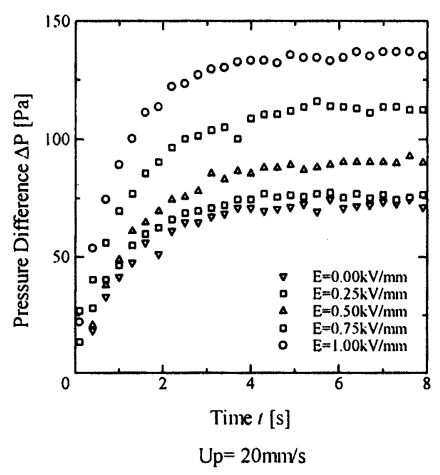

Fig.6 Transient characteristics of pressure difference ( $A s=0.25)$

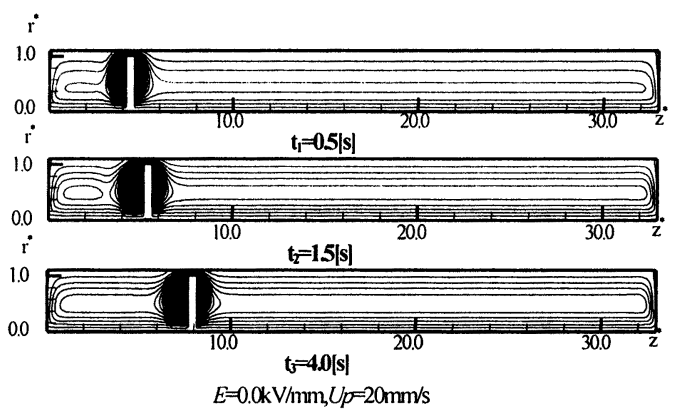

Fig.7 Flow fields $(A s=0.25)$

5·2·2 定常圧力値 アスペクト比が小さいほど差 圧の定常值は小さくなる. 一部のピストン速度が速い条 件を除き, アスペクト比と差圧の值には比例関係が成立 することが確認された。これは前述（差圧理論近似式の 導出）に示されるようにピストンとシリン壁のせん断 応力が作用する面積に依存するためで，アスペクト比の 低下に伴い，ピストン側面に働くせん断力が減少するた めである.

\section{$5 \cdot 3$ 差圧定常値比較}

5.3.1 近似值との比較 差圧の定常值に対して, 図 8 に ER 流体をビンガム流体として求めた理論近似 值と実験值の比較を示す. 図 9 は無電場時におけるピ ストン - シリンダ間隙部の速度分布解析結果を示して おり, 各位置 $P i$ （ピストン前端からの距離）におけ る速度分布を模式的に示したものである. 図8(i)から 分かるようにアスペクト比が大きく, ピストン速度が 遅い場合には, 近似值と実験值は比較的良い一致を示 すことが分かる.このことからこれらの実験範囲にお 
いては, 本研究に用いた ER 流体をビンガム流体とし て扱った 1 次元近似理論式の妥当性が確かめられた. ただし，ピストン速度が大きい $U p=100 \mathrm{~mm} / \mathrm{s}$ の条件で は，最大 17\%の相対差が生じた，さらに図8(ii)に示す アスペクト比が小さい条件ではこの傾向が更に顕著に 現れ，ピストン速度 $U p=100 \mathrm{~mm} / \mathrm{s}$ の条件では実験結果 が近似値を約 39\%上回った. その他の条件でも同様
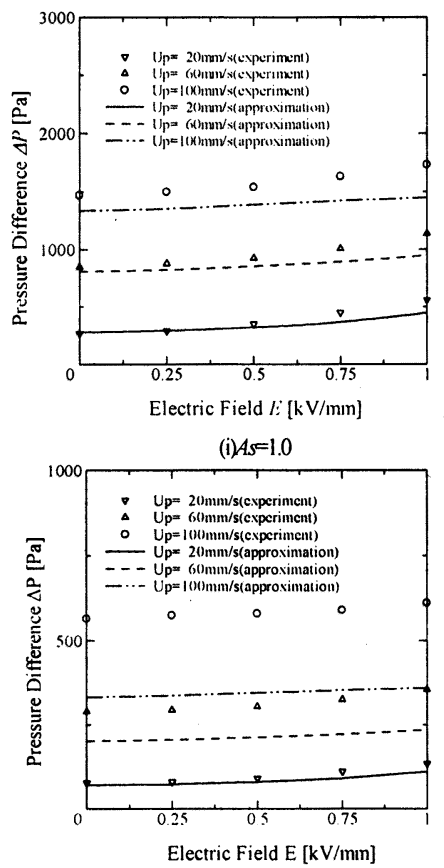

(ii) $A s=0.25$

Fig.8 Comparison between analytical approximation and experiments

の結果が得られており, アスペクト比が小さく, ピス トン速度が大きくなるほど近似值と実験值の乘離が大 きくなる事が確認された。一方，電場条件によって乘 離幅は変化を示しておらず, 粘度の変化と差異の生じ た原因とは無関係であることが分かった. ここで，近 似值と実験值での大きな差異が生じた理由として, ピ ストン運動時における後流渦の影響が考えられるもの の，これは前節（5.2.1）で数值解析結果を踏まえて述 べたとおり，アスペクト比の違いが流れ場の形成に及 ぼす影響は非常に小さいことが確認されている.すな わち, 渦形成などの流れのパターンが圧力の差異に影 響を与えた可能性は非常に低いと考えられる. 次に, ピストンーシリンダ間隙部における速度分布に着目す
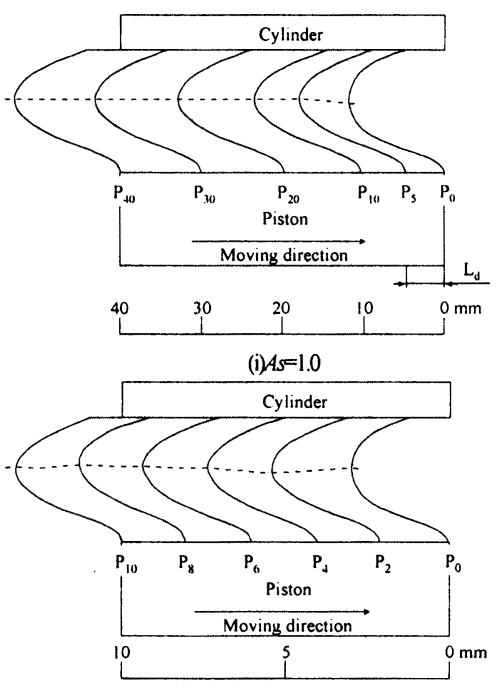

(ii) $A s=0.25$

Fig.9 Velocity distribution in gap space $(U p=60 \mathrm{~mm} / \mathrm{s})$

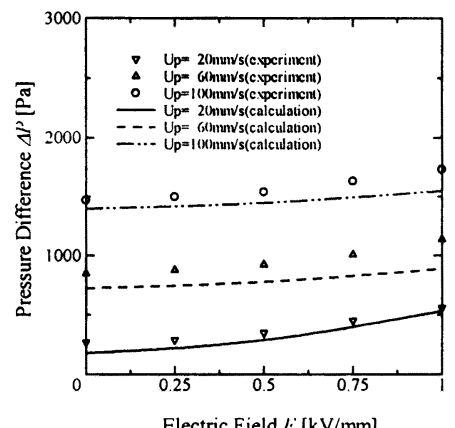

Electric Field $l:[\mathrm{kV} / \mathrm{mm}]$

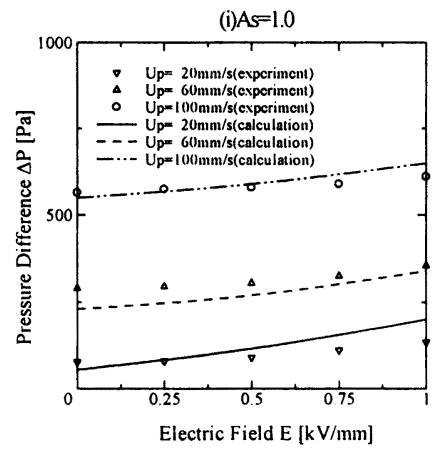

(ii) $A s=0.25$

Fig. 10 Comparison between numerical results and experiments

ると，図9(i)に示されるようにアスペクト比が大きい 条件においてはピストン前端から $5 \mathrm{~mm}$ 付近以降で速 度分布が一致する（流れの発達区間 $L_{d}=5 \mathrm{~mm}$ ）のに対 して, 図9(ii)のアスペクト比が小さい条件においては 
全ての位置で速度分布が一致しない事を確認した。す なわち, アスペクト比が小さいピストン表面において は，発達流れは充分に存在しないことが分かった. す なわち, 本研究で提案した近似式は十分発達した流れ の仮定の下で求められたので, 間隙部分に生じる流れ が充分に発達するまでの距離がピストンに存在しない 場合では, この仮定が成立せず, 近似值と乘離する傾 向が見られるものと考えられる.

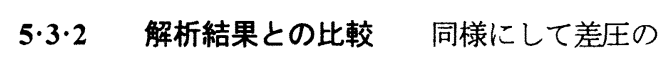
定常値に対して, 図 10 に数值解析により計算した結 果と実験值の比較を示す。図 10(i)，(ii)に示されるよ うに両者の間には良い一致が得られた。すなおち, ピ ストン運動時の差圧を把握するのにピストンーシリン ダ間隙部における 1 次元流れを考慮するだけでは一部 の実験条件を除き不十分であり，2 次元方向でシリン ダ内部を一つの系として計算する必要がある.

\section{6. 結 言}

本研究により，ER 流体を用いたモデルダンパーにお いて以下の結論を得た。

1. 電場を加えることで流動抵抗が大幅に増加し, 差 圧の值が增加することを確認した。

2. 電場印加時に非常に緩慢な流れ場が形成され，ピ ストン速度をステップ的に立ち上げた時の圧力応 答時間が長くなることを確認した.

3. アスペクト比の違いが流れ場の形成に及ぼす影響 は非常に小さく，忘答時閒にも関与しない事を確 認した.
4. 圧力特性を評価する場合, ピストンーシリンダ間 隙部における 1 次元流れを考虑するだけでは不十 分であり， 2 次元方向でシリンダ内部を一つの系 として計算する必要がある.

\section{謝辞}

本研究の遂行には, 文部科学研究費（基盤研究 C）の 補助を得た。ここに記して, 謝意を表す。

\section{参考文献}

(1)Nakae, T., Rheology Engineering and the Applied Technology, Fujitec Corpolation, (2000), pp.781 786.

(2)Takesue, N., et al., ER Effects of Homogeneous ER Fluid on One-Sided Pattem Electrodes, Transactions of the Japan Society of Mechanical Engineers, Series C, Vol.69, No.684, (2003-4), pp.2011-2017.

(3)S.B.Choi et al. Control characteristics of a continuously variable ER damper, Mechatronics 8 (1998), pp.143-161.

(4) Tada, S. and Kabetani, N., Hydrodynamic Behavior of Electrorheological Fluids, Transactions of the Japan Society of Mechanical Engineers, Series B, Vol.63, No.613, (1997-9), pp.2985-2992.

(5)Yamaguchi, H. et al. Pressure characteristics of ER Damper with Different Piston Velocity, International Joumal of Modem Physics B, (2005), in press.

(6) Suhas V. Patankar, NUMERICAL HEAT TRANSFER AND FLUIDFLOW,Morkita Shuppan Co,Ltd, (1985), pp.116-142. (7) Koyama, K. Application \& Development of Electro Rheological Fluid, CMCPublishingCO,LTD.pp.11-13. 